\title{
AN IN VITRO STUDY OF CINNAMOMUM ZEYLANICUM AS NATURAL INHIBITOR OF ANGIOTENSIN-CONVERTING ENZYME (ACE) ON SHEEP (OVIS ARIES) TISSUES
}

\author{
RANJINI H $S^{1}$, PADMANABHA UDUPA E $\mathrm{G}^{1 *}$, SHOBHA U KAMATH ${ }^{1}$, MANJUNATH SETTY², BASAVARAJ HADAPAD ${ }^{3}$, \\ ASHA KAMATH ${ }^{4}$
}

${ }^{1}$ Department of Biochemistry, Kasturba Medical College, Manipal University, Manipal, Karnataka, India. ${ }^{2}$ Department of Pharmacognosy, Manipal College of Pharmaceutical Sciences, Manipal University, Manipal, Karnataka, India. ${ }^{3}$ Department of Ayurveda, Kasturba Medical College, Manipal University, Manipal, Karnataka, India. ${ }^{4}$ Department of Community Medicine, Kasturba Medical College, Manipal University, Manipal, Karnataka, India. Email: padmanabhaudupa.eg@gmail.com

Received: 11 June 2016, Revised and Accepted: 15 June 2016

ABSTRACT

Objective: The present study was aimed to find the angiotensin-converting enzyme (ACE) inhibitory activity using the methanolic extract of Cinnamomum zeylanicum (as a natural inhibitor) on sheep tissues as the enzyme source.

Methods: Hippuryl-histidyl-leucine (HHL) as a substrate, tissue ACE activity was measured spectrophotometrically at $228 \mathrm{~nm}$. For an incubation period of 30 minutes at $37^{\circ} \mathrm{C}$, the linearity of ACE activity of kidney, lung, and testis enzyme was established. A known medicinal plant C. zeylanicum was used as natural inhibitor of ACE. In this enzyme assay, inhibitory effect of methanolic extract of $C$. zeylanicum on kidney, lung and testicular ACE was determined. ACE activity was confirmed by captopril, a standard inhibitor of ACE.

Results: In the presence of a methanolic extract of C. zeylanicum (10:1), ACE activity was determined and this has inhibited ACE activity very significantly. C. zeylanicum leaves extract has reduced sheep kidney, lung, and testis ACE activity by $70.06 \%, 12.63 \%$, and $20.23 \%$, respectively.

Conclusion: Significant inhibition was observed in the kidney ACE than in lung and testis ACE activity. This can propose that there may be a possible role in controlling blood pressure or reduction in cardiovascular diseases. Some plants with the great medicinal property may be considered as promising sources of natural inhibitors of ACE for medicine and commercial uses. This comprehensive study may show numerous beneficial effects as a potential therapeutic agent for lowering blood pressure.

Keywords: Angiotensin-converting enzyme, Natural angiotensin-converting enzyme inhibitor, Kinetic assay, Hippuryl-histidyl-leucine, Cinnamomum zeylanicum, Cardiovascular diseases.

(C) 2016 The Authors. Published by Innovare Academic Sciences Pvt Ltd. This is an open access article under the CC BY license (http://creativecommons, org/licenses/by/4.0/) DOI: http://dx.doi.org/10.22159/ajpcr.2016.v9i5.13424

\section{INTRODUCTION}

Angiotensin-converting enzyme (ACE, EC: 3.4.15.1), a ubiquitous endothelial enzyme, interdigitates via physiologically two critical systems, i.e., Renin-angiotensin system (RAS) and bradykinin pathways. The RAS is involved in the regulation of blood pressure, but it is also important at the microvascular level in the regulation of neovascularization. ACE and angiotensin II (a potent vasoconstrictor) [1] are biologically active components [2,3] in RAS ACE is a bivalent dipeptidyl carboxyl metallopeptidase, endothelial, a luminal surface enzyme that affects multiple systems. Systemic ACE functions in the RAS are controlling fluid balance, blood pressure, and there is also considerable evidence for the potential role of ACE in reproductive functions [4] due to the presence of ACE in testicular Leydig cells. It is also predominantly present in kidney epithelium [5,6]. Some commonly used ACE inhibitors for hypertension, cardiac failure, diabetic nephropathy, acute myocardial infarction [7]are captopril, lisinopril, and enalapril. However, some of them show certain side effects [8]. Excessive use of antihypertensive drugs can cause certain side effects such as cough, hyperkalemia, headache, dizziness, fatigue, nausea, hypotension, and renal impairment [9]. In such cases, maybe, the use of herbal drugs as therapeutic agents may aid to prevent hypertension with enhancement of metabolic health [10]. Large numbers of natural inhibitors such as gooseberry, gokshura, rose petal jam, turmeric, ginger, cinnamon, and cardamom are well known for their hypotensive action [11].

Cinnamon (Dalchini) belongs to genus Cinnamomum, family Lauraceae, which is largely distributed in India. Its bark/crust and leaves are widely used as spices in food or to produce essential oils. It attributes to antioxidant, anti-microbial, anti-diarrheal, anti-ulcer, hypolipidemic, and hypoglycemic activities [12]. The chemical constituents containing are essential oils, resinous compounds, cinnamaldehyde, and cinnamate [13]. These contents are responsible for pungent taste and scent. Cinnamon-like antioxidants are added into food to terminate the free radical chain reaction and delay oxidation process [14]. Cinnamon may prevent myocardial infarction-like complications such as oxidative stress-mediated free radicals and high lipid level through antioxidant defense mechanism and its hypolipidemic activity [15]. It is a known medicinal plant used since ancient time to cure different disease conditions in humans as well as in in vitro studies as potential ACE inhibitors. This plant has selected for the study because it was used as a source of ACE inhibitors in earlier studies and reported inhibition of ACE [16]. However, detailed studies such as isolation of active components and kinetic studies of ACE inhibition from this medicinal plant are not reported. The interaction between inhibitor and different isoforms of ACE may differ each other and it may be possible to elucidate the same in this study. Hence, this study was initiated to analyze the inhibitory effect of methanolic extract of this medicinal plant on kidney, lung, and testis ACE activity using enzyme kinetics.

\section{METHODS}

Hippuryl-histidyl-leucine, Captopril and Bovine serum albumin (BSA) are obtained from sigma chemicals, St. Louis, MO USA. Other chemicals used in this study, are analytical grade(AR) commercial chemicals. 
Collection and identification of plant material

Cinnamomum zeylanicum (Bark) was collected from Basaveshwara estate, Shanivarsanthe, Somwarpete Taluk, Kodagu district, Karnataka. This plant was identified with a botanist and submitted the herbarium of C. zeylanicum to the Department of Pharmacognosy, Manipal College of Pharmaceutical Sciences, Manipal, as well as collected phytochemistry pharmacognosy (PP No: 602A), and the same plant bark was used in the study. Using a blender, dried bark of the plant was ground into a uniform powder and then stored at room temperature.

\section{Estimation of ACE activity}

This study was conducted in the Department of Biochemistry, Kasturba Medical College, Manipal, Manipal University, and there was no ethical issue by the Institutional Animal Ethics Committee, KMC, Manipal, Manipal University (IAEC/KMC/39/2014). From local slaughter house, sheep tissues were collected. An amount of $2 \mathrm{~g}$ of cleaned tissue was homogenized in $10 \mathrm{ml}$ of $0.1 \mathrm{M}$ phosphate buffer (1:5) and centrifuged at $10000 \mathrm{~g}, 4^{\circ} \mathrm{C}$ for 25 minutes. Supernatant was collected and dialyzed using $0.1 \mathrm{M}$ phosphate buffer [17]. Using BSA as standard, protein content was measured by the method of Lowry et al. [18]. Tissue ACE activity was measured by a method modified from Cushman and Cheung using HHL as substrate $[17,19]$. Tissue ACE activity was also measured similarly in the presence of well-known ACE-inhibitor, i.e., captopril as standard. Hence, the amount of enzyme catalyzing the release of $1 \mu \mathrm{mol}$ of hippuric acid per minute at $37^{\circ} \mathrm{C}$ can be defined as one unit of ACE activity $[20,27]$.

\section{Extraction of powdered plant (Bark) material in methanol}

The powder of the plant part is extracted with methanol using a Soxhlet apparatus $\left(60-80^{\circ} \mathrm{C}, 1: 50 \mathrm{w} / \mathrm{v}\right)$ until the last extract is colorless. The combined extract is filtered and the filtrate is concentrated and evaporated on a boiling water bath until to afford the $50 \%$ extract [21]. Tissue ACE activity in the presence of inhibitor (C. zeylanicum [Bark]) was measured from Cushman and Cheung method [17], with $25 \mu \mathrm{l}$ of methanolic exact of inhibitor.

\section{RESULTS}

The percentage of ACE inhibition was compared in tissues from kidney, lung, and testis in triplicates from natural inhibitor as a methanolic extract of $C$. zeylanicum (10:1) and in captopril as standard drug ACE activity was confirmed with specific ACE inhibitor. In this experimental study, the following graphs, for an incubation period of 30 minutes at $37^{\circ} \mathrm{C}$, the linearity of ACE activity of different aliquots from 10 to $50 \mu \mathrm{l}$ of kidney, lung, and testis enzyme was established with HHL as substrate.

\section{DISCUSSION}

In RAS system, angiotensin II as a potent vasoconstrictor increases angiotensin II (Ang-II) level. One of the causes is an increase in blood pressure leading to hypertension [22,28]. Due to over/long use of synthetic ACE inhibitors, some of the side effects are mentioned. To reduce these side effects, $C$. zeylanicum as natural inhibitor can be used. An acceptable increase in ACE activity was observed in Figs. 1-3 though it is a crude extract where concentration was unknown and also could know the concentration of protein in $\mu \mathrm{g} / \mathrm{ml}$. C. zeylanicum has a potential role in inhibiting the activity of enzymes relevant for hyperglycemia and hypertension [23]. In Tables 1 and 2, data were expressed in median and interquartile range (IQR), and ACE activity in kidney, lung, and testis was 17.77 (17.75, 17.79), 21.69 (21.66, $21.74)$, and $29.50(28.90,29.61)$ hippuric acid released/g/minute, respectively. ACE activity was also determined in the presence of C. zeylanicum in kidney, lung, and testis which was $5.32(3.55,5.93)$, $18.95(12.66,20.63)$, and $23.53(16.69,26.1)$ hippuric acid released/g/ minute, respectively, where there is reduction in the ACE activity when compared with the absence of inhibitor. Some studies show that the use of this extract has a significant increase in sperm motility and sperm count $[24,30]$; however, this study does not have any effect on testicular ACE. ACE activity in the presence of standard drug $(50 \mu \mathrm{m})$ captopril was $1.48(1.23,1.66), 8.06(6.71,9.84)$, and $14.37(9.15,16.08)$ hippuric acid released/g/minute and there was a significant decrease in the

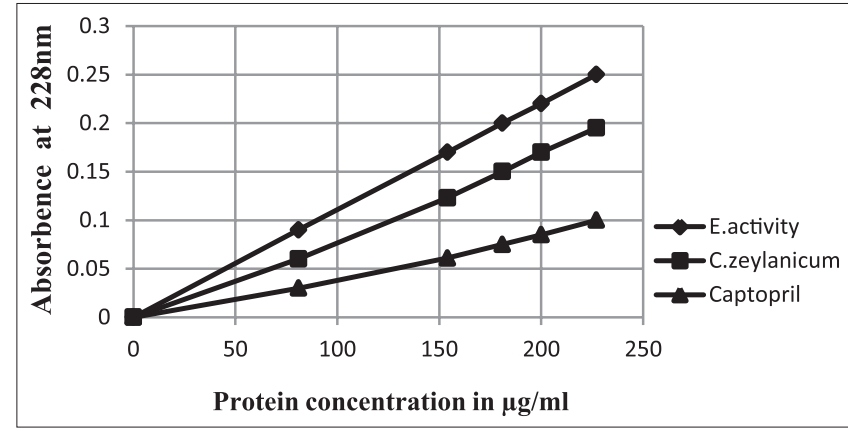

Fig. 1: Kidney

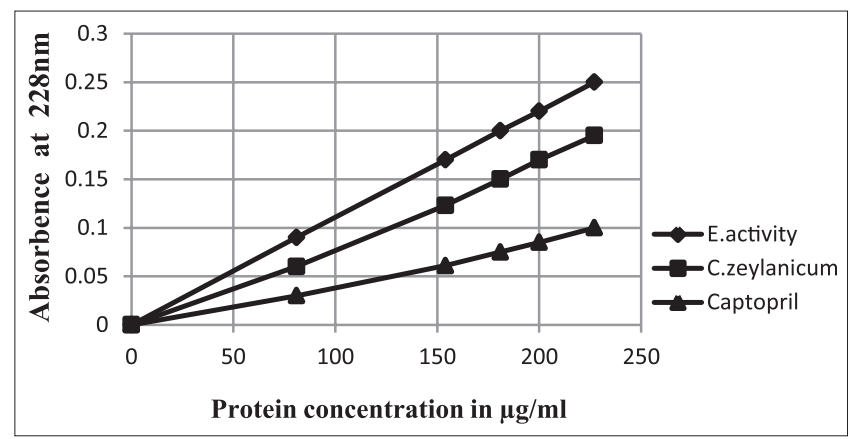

Fig. 2: Lung

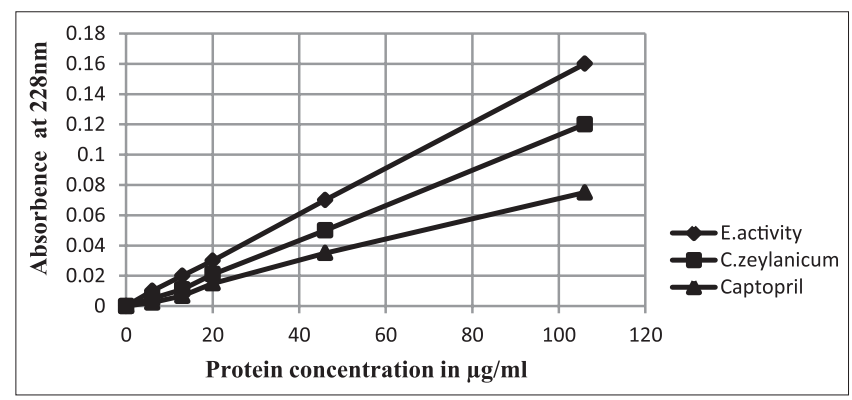

Fig. 3: Testis

ACE activity in $1 \%$ of inhibitor extract. Hence, ACE activity is more in kidney than in lung and testis and also as ACE activity decreases, percentage of inhibition increases. Probably, then, C. zeylanicum as inhibitor might be more effective toward kidney ACE isoform in which can help to correlate the different functions and actions of Ang-II with different isoforms of ACE [29]. Hence, the percentage of ACE inhibition in the presence of $C$. zeylanicum was $70.06 \%, 12.63 \%$, and $20.23 \%$ in kidney, lung, and testis, respectively. Percentage (\%) of ACE inhibition in the presence of captopril was $91.67 \%, 62.84 \%, 51.28 \%$ in kidney, lung, and testis, respectively. Hence, this plant has inhibited ACE activity very significantly. The median value of ACE activity in all tissues in the presence of inhibitor was found to be significant when compared to control $(\mathrm{p}<0.01)$ in Table 1 . The median value of ACE activity in all tissues was statistically significantly different from other two groups $(\mathrm{p}<0.01)$ in Tables 1 and 2. Hence, ACE has been inhibited significantly by $70 \%$ which is almost near to standard drug (captopril), i.e., $91.7 \%$ [27] which is a crude extract. Hence, we can expect much higher inhibition if we could purify the active component from different solvents. Therefore, this plant will be a good antihypertensive agent by inhibiting ACE activity in different tissues.

C. zeylanicum is one of the most well-known natural antioxidants and has been shown to possess various biological properties such as antibiotic, antioxidative, anti-diabetic, anti-influenza, and apoptosisinducing properties [25]. Use of antioxidant containing compounds can 
Table 1: ACE activity in tissues and percentage (\%) of ACE inhibition in presence of Cinnamomum zeylanicum

\begin{tabular}{llll}
\hline Category & $\begin{array}{l}\text { ACE activity in } \\
\text { absence of inhibitor }\end{array}$ & $\begin{array}{l}\text { ACE activity in } \\
\text { presence of inhibitor }\end{array}$ & $\begin{array}{l}\text { \% of inhibition in } \\
\text { presence of inhibitor }\end{array}$ \\
\hline Kidney & $17.77^{*}(17.75,17.79)$ & $5.32^{*}(3.55,5.93)$ & 70.06 \\
Lung & $21.69^{*}(21.66,21.74)$ & $18.95^{*}(12.66,20.63)$ & 12.63 \\
Testis & $29.50^{*}(28.90,29.61)$ & $23.53^{*}(16.69,26.1)$ & 20.23 \\
\hline
\end{tabular}

${ }^{*}$ ACE activity is expressed as $\mu \mathrm{m}$ of hippuric acid released/g/minute, ${ }^{*}$ data is expressed in median (IQR), ${ }^{*}$ number of trials carried is in triplicates ( $\mathrm{n}=3$ ). ${ }^{*} \mathrm{p}<0.05$, ACE: Angiotensin converting enzyme, IQR: Interquartile range, C. zeylanicum: Cinnamomum zeylanicum

Table 2: ACE activity and percentage (\%) of ACE inhibition in presence of captopril

\begin{tabular}{lll}
\hline Category & $\begin{array}{l}\text { ACE activity in } \\
\text { presence of captopril }\end{array}$ & $\begin{array}{l}\text { \% of inhibition in } \\
\text { presence of captopril }\end{array}$ \\
\hline Kidney & $1.48^{*}(1.23,1.66)$ & 91.67 \\
Lung & $8.06^{*}(6.71,9.84)$ & 62.84 \\
Testis & $14.37^{*}(9.15,16.08)$ & 51.28 \\
\hline
\end{tabular}

*ACE activity is expressed as $\mu \mathrm{m}$ of hippuric acid released $/ \mathrm{g} /$ minute, ${ }^{*}$ data were expressed in median (IQR), *number of trials carried is in triplicates ( $\mathrm{n}=3$ ), ${ }^{*} \mathrm{p}<0.05$, ACE: Angiotensin converting enzyme, IQR: Interquartile range

be beneficial toward some studies not only to maintain antioxidants levels in the body but also to treat the long -term complications that can arise $[13,26]$. Therefore, the search for more effective and safer hypotensive compounds from medicinal plants has continued to be an important area of active research.

\section{CONCLUSION}

Using medicinal plants, the study was undertaken in a systematized method in which they may have the property of reducing blood pressure. Due to medicinal properties of $C$. zeylanicum, there was significant inhibition in the kidney than in lung and testis. Inhibition of ACE activity by this plant suggests that there may be a possible role in controlling blood pressure or reduction in cardiovascular diseases. However, this medicinal plant can be considered as one of the promising sources of a natural inhibitor of ACE for medicine and commercial uses. This comprehensive study may show numerous beneficial effects as a potential therapeutic agent for lowering blood pressure.

\section{ACKNOWLEDGMENT}

We sincerely thank Kasturba Medical College, Manipal, Manipal University, for supporting this study.

\section{REFERENCES}

1. Kramkowski K, Mogielnicki A, Buczko W. The physiological significance of the alternative pathways of angiotensin II production. J Physiol Pharmacol 2006;57(4):529-39.

2. Belović MM, Ilić NM, Tepić AN, Šumić ZM. Selection of conditions for angiotensin-converting enzyme inhibition assay: Influence of sample preparation and buffer. Food Feed Res 2013;40(1):11-5.

3. Paul M, Poyan Mehr A, Kreutz R. Physiology of local renin-angiotensin systems. Physiol Rev 2006;86(3):747-803.

4. Sabeur K, Vo AT, Ball BA. Characterization of angiotensin-converting enzyme in canine testis. Reproduction 2001;122(1):139-46.

5. Rogerson FM, Chai SY, Schlawe I, Murray WK, Marley PD, Mendelsohn FA. Presence of angiotensin converting enzyme in the adventitia of large blood vessels. J Hypertens 1992;10(7):615-20.

6. Persson I. Plant-Derived Substances and Cardiovascular Diseases Effects of Flavonoids, Terpenes, and Sterols on Angiotensin-Converting Enzyme and Nitric Oxide. Sweden: Linkoping University; 2009.p.1-27.

7. Heffelfinger SC. The renin angiotensin system in the regulation of angiogenesis. Curr Pharm Des 2007;13(12):1215-29.

8. López-Sendón J, Swedberg K, McMurray J, Tamargo J, Maggioni AP, Dargie $\mathrm{H}$ et al. Expert consensus document on angiotensin converting enzyme inhibitors in cardiovascular disease. Eur Heart J 2004;25(16):1454-70
9. Poole MD, Postma DS. Characterization of cough associated with angiotensin-converting enzyme inhibitors. Otolaryngol Head Neck Surg 1991;105:714-6.

10. Skidgel RA. Basic science aspects of Angiotensin-1 converting enzyme and its inhibitors. Fundamentals of Clin Cardiol 1993;15:399-427.

11. Sarkar C, Bairy KL, Rao NM, Udupa EG. Effect of banana on cold stress test and peak expiratory flow rate in healthy volunteers. Indian J Med Res 1999;110:27-9.

12. Vasanthi HR, Parameswari RP. Indian spices for healthy heart - An overview. Curr Cardiol Rev 2010;6(4):274-9.

13. Salehi P, Asghari B, Esmaeili MA, Dehghan H, Ghazi I. $\alpha$-Glucosidase and $\alpha$-amylase inhibitory effect and antioxidant activity of ten plant extracts traditionally used in Iran for diabetes. J Med Plants Res 2013;7(6):257-66.

14. Saeidnia S, Abdollahi M. Toxicological and pharmacological concerns on oxidative stress and related diseases. Toxicol Appl Pharmacol 2013;273(3):442-55.

15. Iyer A, Panchal S, Poudyal H, Brown L. Potential health benefits of Indian spices in the symptoms of the metabolic syndrome: A review. Indian J Biochem Biophys 2009;46(6):467-81.

16. Ranasinghe P, Jayawardana R, Galappaththy P, Constantine GR, de Vas Gunawardana N, Katulanda P. Efficacy and safety of 'true' cinnamon (Cinnamomum zeylanicum) as a pharmaceutical agent in diabetes: A systematic review and meta - analysis. Diabet Med 2012;29(12):1480-92.

17. Ranjini HS, Padmanabha Udupa EG, Thomas JM. Angiotensin converting enzyme (ACE): Inhibition of sheep kidney and lung ACE In vitro by Rauwolfia serpentina and Allium sativum. Scholars J Appl Med Sci (SJAMS) 2015;3(5B):1936-40.

18. Lowry OH, Rosebrough NJ, Farr AL, Randall RJ. Protein measurement with the Folin phenol reagent. J Biol Chem 1951;193(1):265-75.

19. Ondetti MA, Cushman DW. Enzymes of the renin-angiotensin system and their inhibitors. Annu Rev Biochem 1982;51:283-308.

20. Udupa EG, Rao NM. Sheep testicular and epididymal angiotensin converting enzyme: Inhibitions by captopril, lisinopril and enalapril. Biochem Mol Biol Int 1997;43(5):1063-70.

21. Rao NM, Udupa EG. Effect of chloride and diamide on sheep kidney, lung and serum angiotensin converting enzyme. Indian J Clin Biochem 2008;23(1):53-6.

22. Soffer RL. Angiotensin-converting enzyme and the regulation of vasoactive peptides. Annu Rev Biochem 1976;45(1):73-94.

23. Maluf-Meiken LC, Fernandes FB, Aragão DS, Ronchi FA, Andrade MC, Franco MC, et al. N-domain isoform of Angiotensin I converting enzyme as a marker of hypertension: Populational study. Int J Hypertens 2012;2012:581780.

24. Ranilla LG, Kwon YI, Apostolidis E, Shetty K. Phenolic compounds, antioxidant activity and in vitro inhibitory potential against key enzymes relevant for hyperglycemia and hypertension of commonly used medicinal plants, herbs and spices in Latin America. Bioresour Technol 2010;101(12):4676-89.

25. Shah AH, Al-Shareef AH, Ageel AM, Qureshi S. Toxicity studies in mice of common spices, Cinnamomum zeylanicum bark and Piper longum fruits. Plant Foods Hum Nutr 1998;52:231-9.

26. Yang EJ, Kim SI, Hur JM, Song KS. Roasting process enhances the antioxidative effect of cinnamon (Cinnamon cortex) via an increase in cinnamaldehyde content. J Korean Soc Appl Biol Chem 2009;52(5):443-7.

27. Rao NM, Udupa EG. Angiotensin converting enzyme from sheep mammary, lingual and other tissues. Indian J Exp Biol 2007;45(11):1003-6.

28. Vickers C, Hales P, Kaushik V, Dick L, Gavin J, Tang J, et al. Hydrolysis of biological peptides by human angiotensin-converting enzymerelated carboxypeptidase. J Biol Chem 2002;277(17):14838-43.

29. Ferrario CM, Jessup J, Chappell MC, Averill DB, Brosnihan KB, 
Tallant EA, et al. Effect of angiotensin-converting enzyme inhibition and angiotensin II receptor blockers on cardiac angiotensin-converting enzyme 2. Circulation 2005;111(20):2605-10.
30. Turner AJ, Hooper NM. The angiotensin-converting enzyme gene family: Genomics and pharmacology. Trends Pharmacol Sci 2002;23(4):177-83 